\title{
全方位視覚を用いた案内ロボットシステム
}

\author{
非会員 佐藤和也 (大阪大学) \\ 非会員 山澤一誠 (奈良先端科学技術大学院大学) \\ 非会員 八木康史 (大阪大学) \\ 非会員 谷内田正彦 (大阪大学)
}

\section{Autonomous Guidance Robot System with Omnidirectional Image Sensor}

\author{
Kazuya Sato (Osaka University) \\ Kazumasa Yamazawa (Nara Institute of Science and Technology) \\ Yasushi Yagi (Osaka University) \\ Masahiko Yachida (Osaka University)
}

\begin{abstract}
Described here is a guide mobile robot system for following a user and navigating the user to the desired position in the environment such as museum or exhibition. The system acquires an omnidirectional information around the robot, in real-time, with multiple sensors such as the omnidirectional image sensor HyperOmniVision, omnidirectional ultrasonic sensors, etc. Since HyperOmni Vision observes a 360 degree view around the robot, it can observe a global and precise azimuth information of features, however, it is difficult to estimate the precise location of a moving object (user) from azimuth information. On the other hand, The system has active sensors such as omnidirectional ultrasonic ranging sensors and obtains range data around the robot. However, the azimuth resolution is poor and it is not suitable for the object recognition. Therefore we integrate both sensors' merits. HyperOmni Vision identifies and tracking the user by using the azimuth and color information. Furthermore, the location of the robot is estimated by HyperOmni Vision. The robot follows and navigates the user with the constant distance between the user and the robot by using azimuth information (HyperOmni Vision) and range information (Ultrasonic Sensors).
\end{abstract}

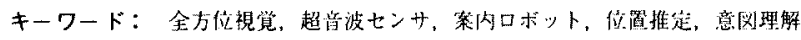

\section{1.まえがき}

ホームロボットや介護ロボット，案内ロボットなど人 間が生活する空間で人間と共存するロボットのための研究 が盛んに行われている[1,2,3]。このような奏世界を意識し た場合，環境内には，構造物だけでなく人間が存在する。 従って，人間を含む環境内を対象とした移動ロボットは， 単に環境に対する位置関係を把握するだけではなく，人間 一環境ーロボット三者間の関係を考慮に入れた観測、並び に人との協調行動を行なわなくてはならない。

環境一ロボット間については、これまで多くの研究が なされてきた。特に静的環境を対象としたものは，環境 地図を利用した自己位置推定方法やランドマークを記憶 する誘導方法など様々なロボット誘導方法が提案されて いる[4,5]。また静止環境だけでなく人間を含む動的な環 境に対しても，人間を移動障害物として扱うことで歩行 者と衝突することなく移動できるロボットシステムや前 方の人物を発見し追跡するシステムなど，人間一ロボッ 卜間を扱った研究が行われている[6,7]。動的な環境を対
象とすることは，実世界を移動するロボットための必要 条件と言える。

しかし，案内ロボットや介護ロボットなど人間と口ボッ トのコミュニケーションが重要な要素となる場合，人を移 動物体として扱㧍うだけでなく，ロボットが人の意図を理 解することが必要不可欠な機能として要求される[8]。口 ボット (計算機)による人間の意図理解に関する研究とし ては，視覚情報からの人のジェスチャ認識や表情認識や音 声情報からの話者の行動理解に関する研究など $[9,10,11]$ があるが，実世界にロボットが使われることを考虑すると，

人間とロボット間の関係だけでなく。本来，人間一環境 ーロボット三者間の関倸を考慮する必要がある。

本研究では，人間一環境一ロボット三者間の関係に重 点を置き，人間と共にロボットが行動することで人間の意 図をロボットの動作結果として理解する自律移動ロボット システムの構築を目的とする。具体的には，全方位視覚七 ンサHyperOmini Visionを搭載した自立移動ロボット Nomad200が，美術館のような建物内に桧などのパネルが 複数かかっている環境に扔いて，人間とともに歩き回り， 
ユーザの希望するパネルを推定する案内ロボットシステム を構築する[12]。

ロボットが自律的に行動するためには，周囲の環境と 自己位置ならびに人間とロボット自身の位置関係（方位と 距離）を把握する必要がある。そこで周囲環境の把握には, これまで我々が提案してきた全方位視覚センサ HyperOmini Vision[13]を用い，環境マップと観測情報と の照合によりロボットの誘導を行う[14]。さらに, ロボッ トのナビゲーションに人間の意図を考虑に入れるならば, ロボットの行動指針となる人間の行動を理解しなければな らない。そこで, 人間とのインタラクションでは, 全方位 視覚センサに全方位超音波距離センサ及び全方位赤外線近 接センサを加えた複数のセンサ情報の統合によって，ロボッ トと人間の位置関係を推定し, ロボットが人間と共に行動 することで, ロボットの行動を通して得られる人間の移動 方向や歩行速度から人間の意図を読みとり案内を行う。

以下， 2 章で移動ロボットの構成， 3 章で時系列差分と 色情報を用いた人物の同定並びに追跡方法, さらに全方位 視覚からの観測方位情報を基にした環境に対するロボット の自己位置同定方法, 全方位視覚と超音波距離センサ情報 の統合による人の行動推定方法, 4 章で奏験と検討につい て報告する。

\section{2. システム構成}

<2・1>ハードウェア構成＼cjkstart本システムのハードウェ ア構成を図1に示す。本システムは，移動ロボット Nomad200・RadioEthernetアンテナ等からなる移動ロボッ 卜部, 全方位視覚センサHyperOmni Vision ·画像送信機か らなる全方位視覚部そして画像受信機・画像処理プロセッ サ・ワークステーション等からなるデータ処理部から構成 される。

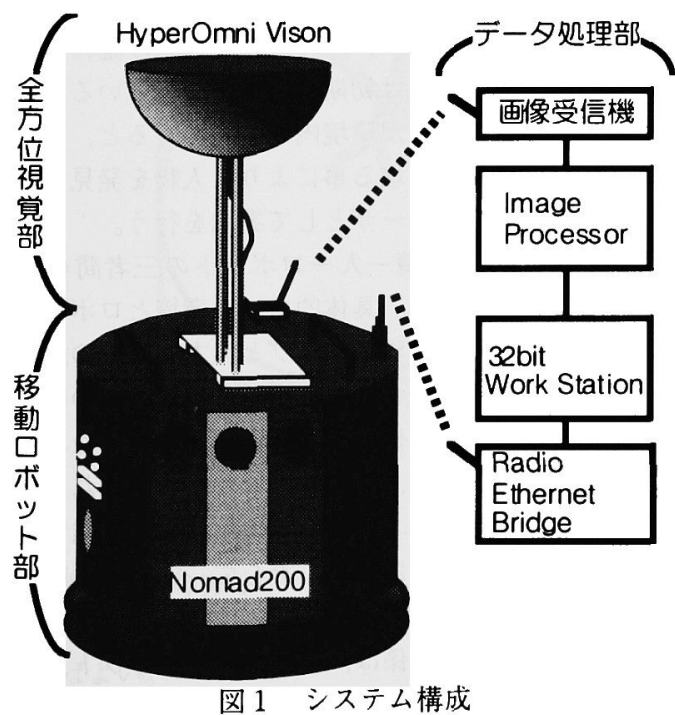

Fig.1. System Configuration

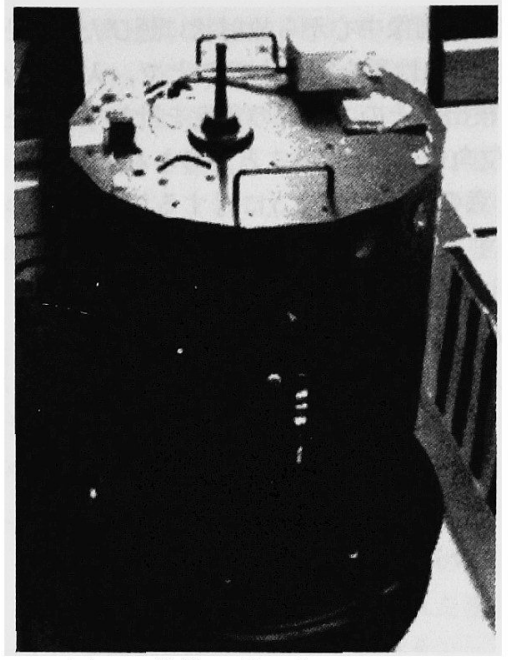

図 2 移動ロボットNomad200

Fig.2. Mobile Robot Nomad200

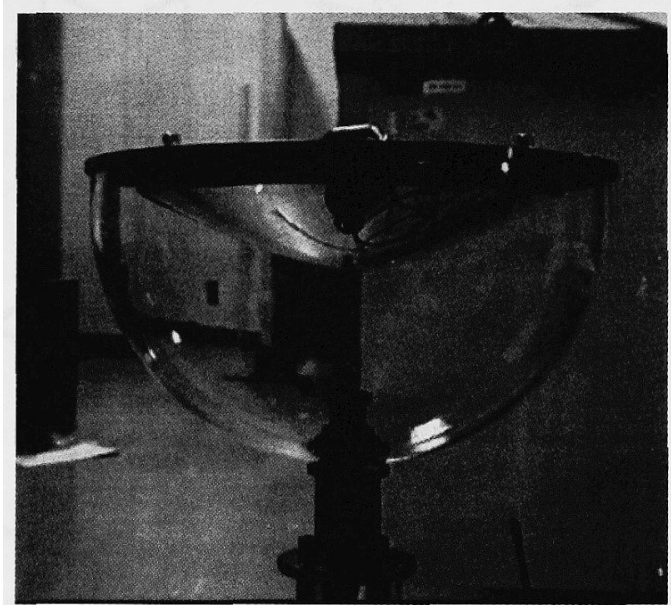

図 3 全方位視覚センサHyperOmni Vision

Fig.3. Omnidirectional Image Sensor HyperOmni Vision

<2・2>移動ロボット部図 2 に示す移動ロボット Nomad200は，円筒の形状をして扔り上部に超音波センサ， 下部に赤外線センサを各々 16 個持っており，ロボットの 回りの距離情報を得ることができる。またロボットは RadioEthernetで遠隔接続されたワークステーション上の制 御用プログラムNserverによって制御される。

$<2 \cdot 3>$ 全方位視覚部全方位視覚部は全方位視覚七 ンサHyperOmni Visionと得られた画像をデータ処理部に UHF電波で送信する画像送信機とからなる。

全方位視覚センサHyperOmni Visionの外観図を図2-2に 示す。HyperOmni Visionは鉛直下向きの双曲面ミラーと鉛 直上向きのカメラから構成され，側方 360 度及び下方を一 度に撮像できる。

従来我々が研究してきた円錐ミラーを利用した全方位視 覚センサCOPISでは, 図2-3のように環境内の垂直エッジ 
は，画像中で画像中心から放射状に延びた線分として現わ れる[14]。この性質を利用することで，入力画像中で放射 エッジを検出，そのエッジの角度を計算することで，对象 物体の方位角 $\theta$ を推定することができる。例えば，垂直エッ ジ上の任意の点 $\mathrm{P}\left(\mathrm{X}_{\mathrm{p}}, \mathrm{Y}_{\mathrm{p}}, \mathrm{Z}_{\mathrm{p}}\right)$ に対する画像面上の写像点を $\mathrm{p}\left(\mathrm{x}_{\mathrm{p}} \mathrm{y}_{\mathrm{p}}\right)$ とすると, 次式の関係が成り立つことからもわか る。

$\tan \theta=\mathrm{Y}_{\mathrm{p}} / \mathrm{X}_{\mathrm{p}}=\mathrm{y}_{\mathrm{p}} / \mathrm{X}_{\mathrm{p}}$

HyperOmni Visionは，この性質をそのまま受け継ぎ，さ らに一般のカメラで撮蔵した画像に変換できるという特徽 を持つ。またHyperOmni Visionでは，カラーカメラを搭載 しており色情報を扱うことができる。詳細に関しては参考 文献を参照されたい[13]。

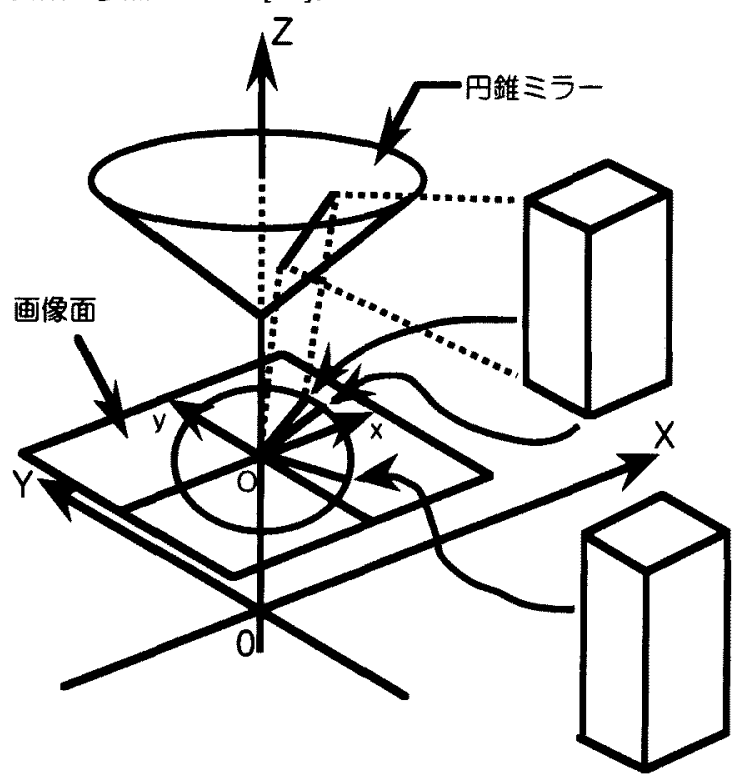

図4 円錐投影

Fig.4. Conic Projection

<2・4>データ処理部移動ロボットからUHF電波で 送られた画像は，映像受信機で取り込まれ，画像処理装置 ITIに送られディジタル画像に变換される。画像処理装置 IT1はワークステーションによって制御され，入力画像か ら各種データを抽出する。得られたデータはワークステー ション内で処理され, 同じくワークステーション上で動作 するロボット制钭用プログラムNserverにより移動ロボッ トを制御する。

\section{3. 案内ロボットシステム}

人間とロボットの共存を考えた場合，人間一環境一ロ ボット間の関係を意識したロボットシステム造りが必要と なる。本手法では，人間一環境一ロボット三者間の観測と ロボットの動作結果からユーザの意図を理解する。具体的 には、ユーザとロボット間の距離を一定に保った定間隔動 作をロボットが能動的に行うことで，ユーザの行動をロボッ
トの行動として扱い，行動の変化からユーザが希望する説 明内容を察知し，案内ロボットはその内容についての説明 を行う。以下，実際に構築した案内ロボットシステムの詳 細について述べる。

$<3 \cdot 1>$ 前提条件本研究では，環境，移動口ボット， ユーザに対して以下のような前提条件を置く。

○ロボットは床面が水平で壁や柱が垂直に立っ ている室内等の人工環境を移動する。

○ロボットは, 予め環境内の垂直エッジ情報, サブゴール位置, ロボットの初期位置からな る環境地図を持っている。

○初期状態で環境内に動物体は存在しない。ユ一 ザは後から環境に入り，案内を受ける。

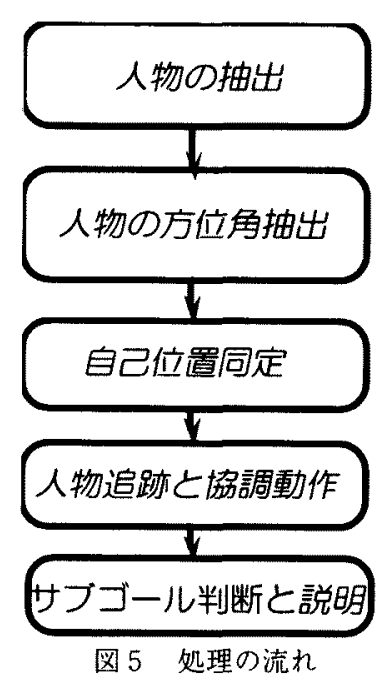

Fig.5. A Sequence of Guidance

$<3 \cdot 2>$ 処理の流九 本システムの処理の流れを図 5 に示す。当初，ロボットは初期位置で待機している。この 状態でユーザとなる人間が環境内に入ってくると，入力画 像と背景画像との差分を取る事により，人物を発見する。 この発見された人物をユーザとして案内を行う。

本システムでは，環境一人ーロボットの三者間の関係 を扱うことを特徴とする。具体的には，環境とロボットの 関係は，予め与えられた環境マップと入力画像との对応付 けを行うことで環境に対するロボットの自己位置の同定を 行う。人とロボットの関係では，上記の発見されたユーザ 領域を時采列間で追跡し，超音波センサから得られる距離 情報と合わせることで，ユーザとロボット間の距離を一定 に保った動作をロボットは行う。そして，定間隔行動を行 うことで，人の行動をロボットの動作変化としてとらえる。

そして環境と人との関係は，上記の人一ロボット，環境 一ロボットの両関倸から，ロボットを介して記述すること ができる。例えば，あるバネルがある場所の近辺でユーザ が立ち止まった場合，ロボットの移動速度の隇少とパネル

(環境) に対するロボットの位置関係から、ユーザがその 
パネルに興味をしめしているのではないかという予測を行 うことができる。以下，各処理内容について説明する。 $<3 \cdot 2 \cdot 1>$ 人物の発見前提条件より, 図 6 のよう に, 未知移動物体のない初期状態の輝度画像を記録してお き，現在の輝度画像との差分を取る。人間が環境内に入っ てくると，人物領域のみが差分の結果としてあらわれる。 2 值化して差分領域の重心を求めることで画像中での人物 の位置を推定する。次に重心を中心とする人物領域の面積 に比例した大きさの正方形領域について, 輝度・色相・彩 度の色情報を抽出する。

以上の处理をユーザが近づいてくる間，くり返し継続し て行い, 計測された各色情報を累積加算し, 輝度・色相・ 彩度のヒストグラムを作成する。そして頻度の高い（所定 のしきい值以上の) 特徵をユーザを表す特徴として, 人物 追跡のため色テンプレートとする。

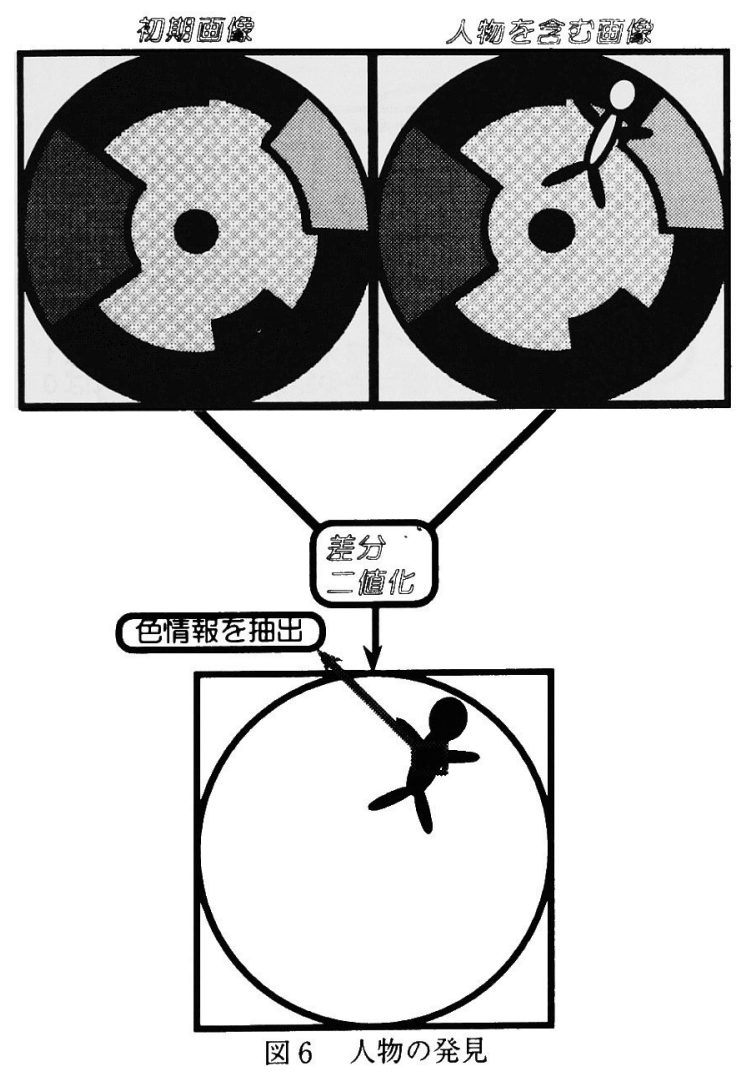

Fig.6. User Identification

$<3 \cdot 2 \cdot 2>$ 人物の方位角抽出移動中にロボットか ら見て人物がどの方位にいるかは，全方位視覚センサの特 徵により，画像中で人物が中心からどの方位に見えるかを 調ベればよい。

具体的には，図 7 に示すように，前節で得られた色テン プレートにより入力画像を 2 值化し，方位角を求める。1 つの要素ではノイズの影響を受けやすく，人物の方位を正
確に抽出することが困難である。そこで, 色相・彩度の 2 要素をそれぞれについて 2 值化しANDを取る。こうするこ とで, ノイズを防ぐことが出来る。さらに, 得られた 2 值 化画像の中で面積がある程度以上の領域のみの重心点を求 めて方位角の抽出を行うことで, 確実に人物の重心点を求 める。得られた画像の画像中心を原点とした重心点を $\left(\mathrm{X}_{\mathrm{m}}\right.$, $\mathrm{Y}_{\mathrm{m}}$ ) とすると, 全方位視覚の性質により, 人物方向 $\theta$ は,

$$
\tan \theta=\frac{Y_{m}}{X_{m}}
$$

で表わすことができる。

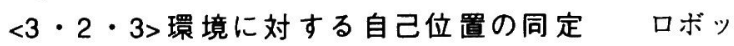
トのエンコーダから大まかな移動量はわかるが正確にはわ からない。そこで自己位置の同定には環境内の垂直エッジ を用いる。予め作られた環境地図と観測された垂直エッジ とを対応付けることで自己位置の同定を行う。

まず，あらかじめ与えられた環境マップと大まかな移動 量から観測されるエッジ方位が予測できる。次に入力画像 から得られるエッジの方位角と環境マップから得られた予 想方位角との比較により対応位置を推定する。環境と対応 付いたエッジからロボットの自己位置を同定する。また， 対応が得られなかったエッジは未知物体として検出し環境 マップに登録する。なお，詳細は参考文献を参照されたい $[14]$ 。

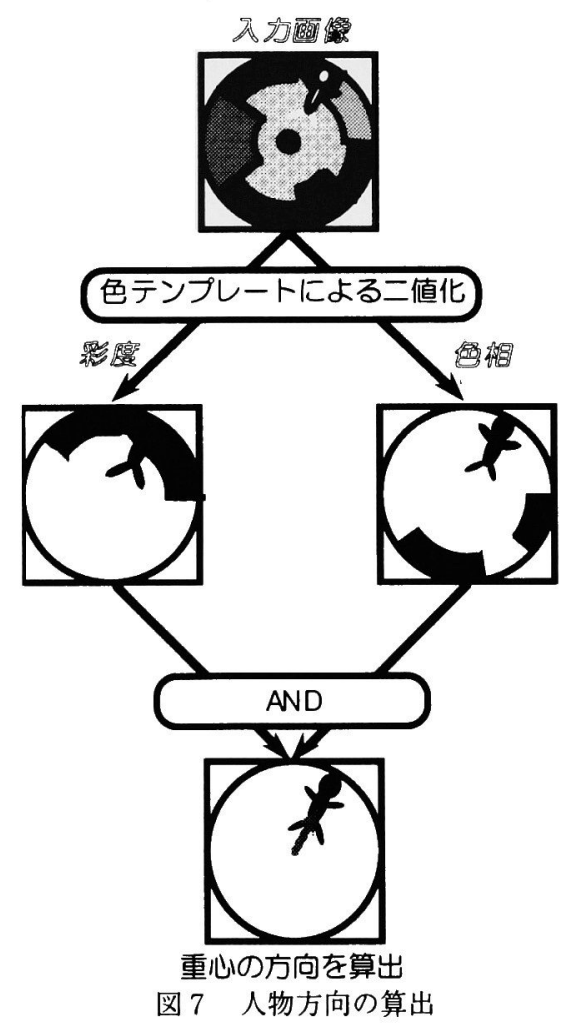

Fig.7. Estimation of User Direction 
<3・2・4>人物追跡と協調動作-定間隔動作 -

本手法では，全方位視覚HyperOmni Visionからの色情報 並びに方位情報，超音波センサと赤外線センサからの距離 情報を融合することで，人物の追跡を行う。

HyperOmni Visionは，<3・2・1>節の方法により人物 領域の色情報を切り出し，その色情報の領域を追跡するこ とで，ロボットが移動しながらでも，人物の方向を抽出す ることが容易に行えるが, HyperOmni Visionは通常の単眼 カメラと同样に，権測対象とロボットが相対的に移動して いる場合，スケールファクタがないため，正確な距離の計 測は困難である。一方，環境にも依存するが一般に，赤外 線センサは近距離を測定するのに適しており，超音波セン サは数メートルから10メートル程度の中距離を測定する のに適している。即ち，各々可観測範囲は異なるが超音波 センサ，赤外線センサは能動的に対象までの距蜼情報を獲 得できるため，相対運動する対象に対しても距離計測を行 うことができるなどの利点がある。しかし，超音波センサ， 赤外線センサ共, 距離計測した対象が何であるかというこ とは判らない。そこで，これらの複数のセンサを用い，そ れぞれのセンサの得意とする情報を統合することで,より 確実で安定した人間の追跡を行う。つまり, 視覚センサの 色情報から人物の方位を抽出し, 距離センサで人物までの 距離や周囲環境の距離を測定し、これらのセンサ情報の統 合により，人物の追跡を安定に行う。

具体的には，<3・2・2>節で求められた人物の方位角 から, 現在のロボットの進行方向との角度差を求める。次 に，ロボットの進行方向に対し左右 60 度以内に人物が観 測されるようにロボットは旋回行動を行う。この旋回動作 時には，環境中の障害物との干涉チェックのためにロボッ トの回りの超音波，赤外線両センサの距離情報を利用する。 特に，赤外線センサの值は非常に近い距離しか検出できな いので，反応があれば衝突の危険があると判断し，回避動 作を行う。以上の行動に上り，目標人物が進行方向に対し て左右 60 度以内に観測できればロボットは人物方向に前 進し，一定間隔の動作に入る。

具体的には，Nomadの運動は，前進速度と回転速度によ り定義され，図 8 に示すように，前進速度は，最大ロボッ ト移動速度に距離センサからの距離情報を0からにまでに 正規化したセンサ值と人物方位角と進行方向の角度差 $\theta$ と により式（3）で定義する。また図 9 に示すように回転速 度は，最大回転速度に人物方位角と進行方向の角度差 $\theta$ と 距離センサの情報 $\alpha$ を掛け合わせた式（4）で表現する。 速度がプラスなら左回り，マイナスなら右回りとなる。左 右の距離センサの情報は，旋回時の衝突危険性の評価を行っ ている。

前進速度 $=$ 最大速度 $\times \cos \theta \times$ センサ值 ․ . (3)

回転速度 $=\left\{\begin{array}{l}\theta<-15 \text { 度なら右回りに最大速度 } \\ \theta>15 \text { 度なら左回りに最大速度 } \\ -15<\theta<15 \text { な 最大速度 } \times \theta / 15 \times \alpha \times \sin \theta\end{array}\right.$
以上の処理を行い, ロボットはユーザとの間隔を一定に保っ た定間隔動作を実現し，定間隔動作時のロボットの移動速 度の変化を観測することで，ユーザの行動を理解する。

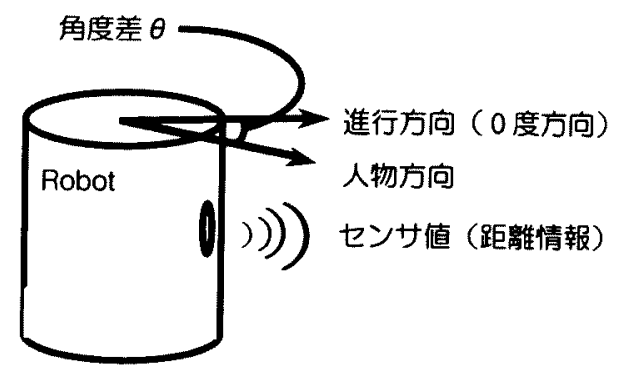

最大距離より大きければ 1

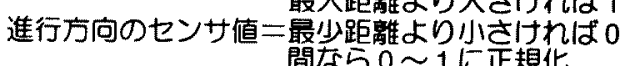

図 8 ロボットの移動速度

Fig.8. Velocity of The Robot
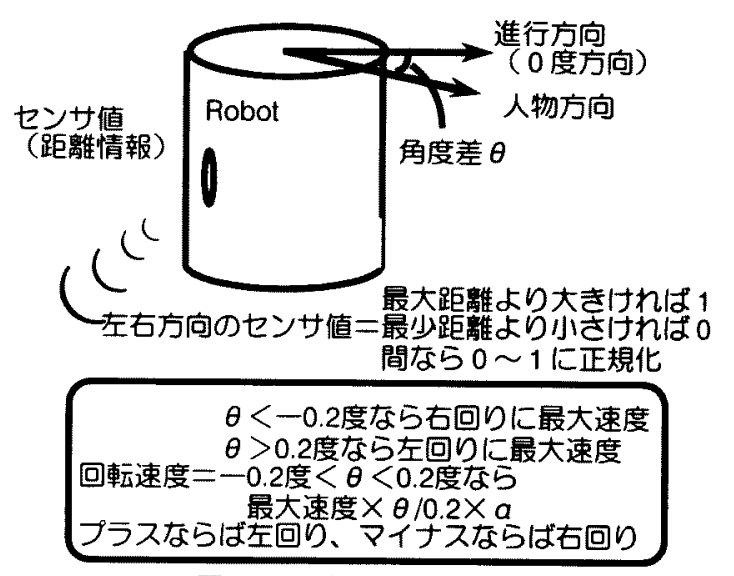

図 9 ロボットの回転速度

Fig.9. Angular Velocity of The Robot

$<3 \cdot 2 \cdot 5>\quad$ サブゴールの判断と説明一般に, 環境内で絵画等が展示されている場所では，人間は興味が あれば立ち止まるし，興味がない場合は，通り過ぎる。即 ち, 人の歩き方の変化（隇速, 停止)は, 人間の周用環境 に対する興味度を知るために手がかりとなる。本節では， 人間と環境との観察の一例として，ロボットの速度変化を 観測することで，人間の興味が環境内のどの部分にあるの かを推定する方法について述べる。

本システムでは，ロボットと人物間の距離を一定に保 つ定間隔動作を行っている。従ってロボットが人物を追跡 する際，人物に近づくにつれて両者の相対移動速度は小さ くなり，最終的にはロボットは一定間隔を保ちながら人物 を追跡しようとする。即ち,この定間隔動作は, 安全距離 を保った走行だけでなく，ロボットの移動速度が人間の移 動速度となるので，人間の歩き方(ここでは歩行速度）の 变化は，ロボットの移動速度の変化を観察することで知る 


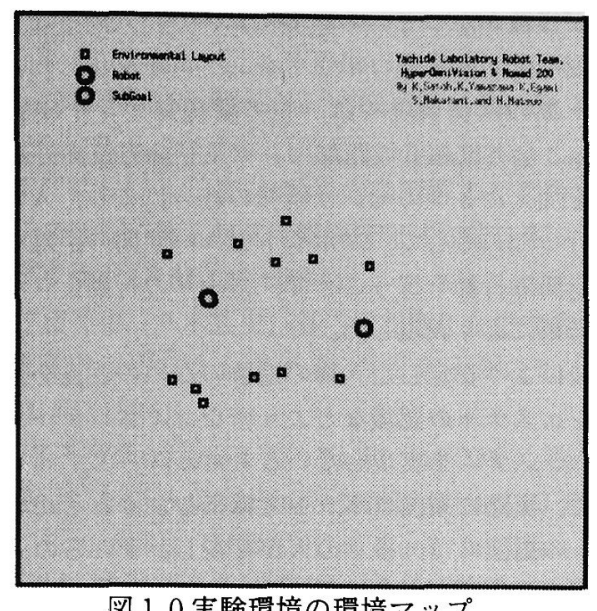

図 10 実験環境の環境マップ

Fig.10. Given Map of Experimental Environment

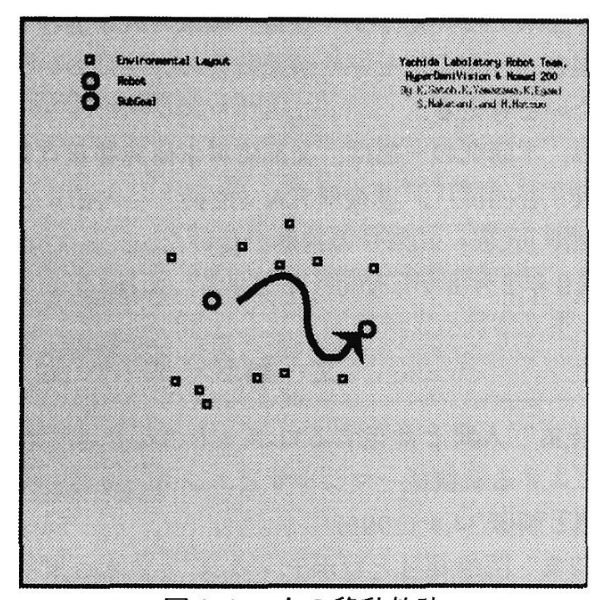

図 111 人の移動軌跡

Fig.11. Trajectory of User

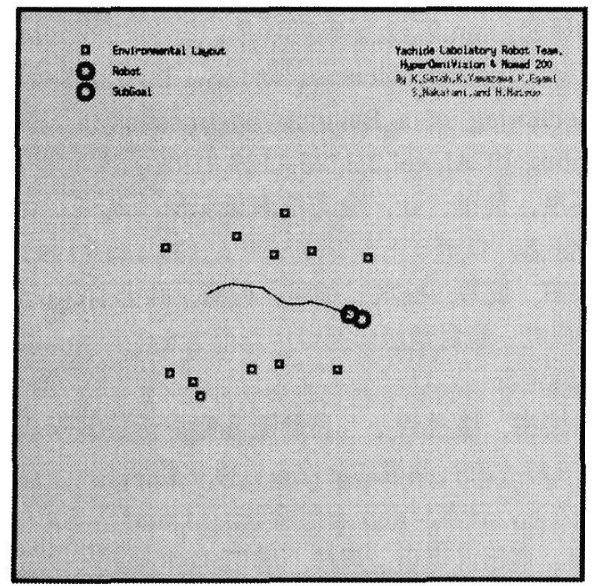

図 13 ロボットの移動軌跡

Fig.13 Robot Trajectory obtained by Internal Encoder

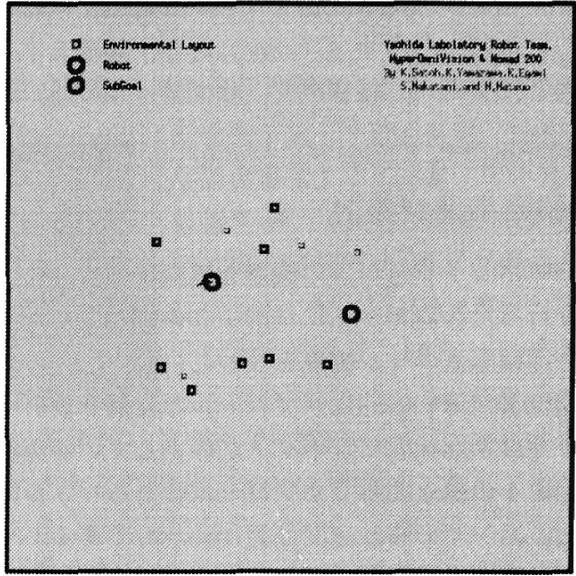

図 12 (a) 実験結果（4フレーム目）

Fig.12(a). Experimental Results (4th frame)

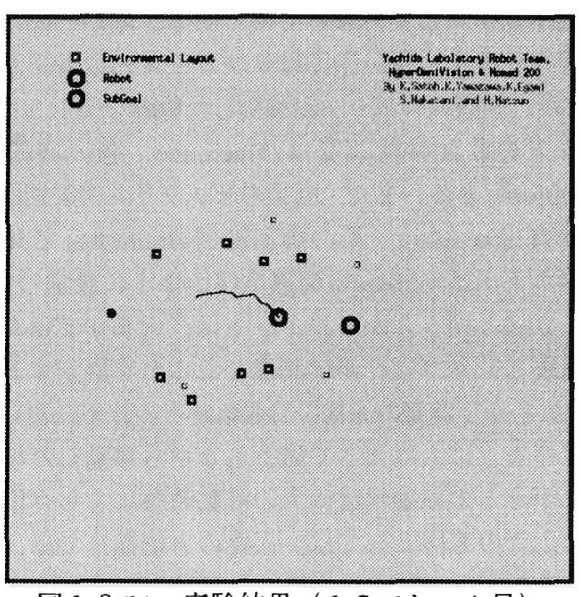

図 12 (b) 実験結果（15 フレーム目）

Fig.12(b). Experimental Results (15th frame)

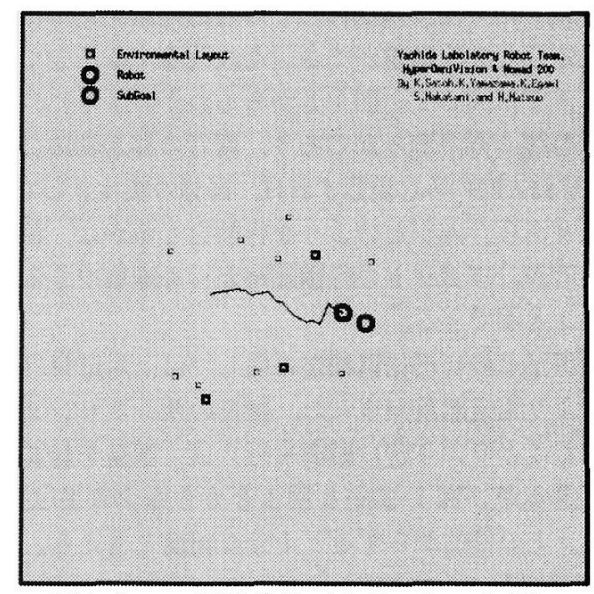

図 12 (c) 実験結果 (27フレーム目)

Fig.12(c). Experimental Results (27th frame) 
ことができる。例えば，サブゴールの近辺で人物が立ち止 まっていれば，そのサブゴールに対し，興味を示している と推察し、ロボットは音声で, サブゴール(絵)の説明を 行う。

\section{4. 実験結果及び検討}

案内口ボットシステムの機能を実際に検討するために， 実験を行った。ロボットには図 10 の様な環境地图を与え る。口印は垂直エッジ位置を表わし，濃い○印はロボット の初期位置, 薄い○印はサブゴールの位置を表わす。

ユーザは初期状態でロボットが静止している環境に進入 し，図11の様な軌跡でサブゴールであるパネルの元に移 動した。ユーザの移動速度は約 $10 \mathrm{~cm} / \mathrm{sec}$ である。

ロボットが自己位置を同定しながら追跡する様子を図 1 2に示す。図中の太い口印は与えられた垂直エッジの内で， 現フレームで自己位置の同定に使用しているものであり， 紐い口印は使用していないものである。濃い○印はロボッ トの現在位置を、薄い○印はサブゴールの位置を示してい る。また，害際のロボットが移動した軌跡を図15に示す。 ロボットの最大移動速度は $15 \mathrm{inch} / \mathrm{sec}$, 最大回転速度は $100 \mathrm{deg} / \mathrm{sec}$ である。また，画像のサンプリング周期はロボッ 卜移動時1 frame/sec，その場回転時4frame/secである。人 間とロボットは約 $50 \mathrm{~cm}$ の間隔を保つように設定した。

図 12 (c)と図 13 からロボットは，大まかではあるが, 人を追跡し，サブコールに到達したことを同定することが できた。しかし実際の人間の行動軌跡との比較においては， 図11のように人は大きく蛇行しながら移動したのに对し て, ロボットの移動軌跡は人の移動軌跡にくらべ滑らかで あった。この原因としては，人物の方位推定では，最初に 抽出した色テンプレートと同じ色領域を抽出し，その色領 域の重心位置から求めているため，照明条件などに影響さ れやすいためと思われる。濃淡またカラーテンプレートマッ チングなどの方法で領域としての対応位置を見つければ， より安定した方位推定ができ，今後改良する予定である。 ところで, 図 11 と図 13 からもわかるようにロボット の移動軌跡の方が滑らかであり，両者の移動轨跡に差があ るが，移動方向のみに着目すれば，同様の変化をしている。 このことから，人がどのような行動をとるかは，程度の違 いはあるが，ロボットの行動軌跡からも推察できるものと 考えることができる。

次にロボットの自己位置推定に関しては，対応付けの誤り などにより推定誤差が現れた。観測のサンプリング周期を 短くすることでより密に観湘を行えば，誤差を軽隇するこ とができるが, 図 12 (c)と図13からもわかるように案 内口ボットの目的からすると十分な精度と言える。

5.おわりに

本研究では，環境一人ーロボット三者の関係をロボット の観測を通し獲得し，人間と協調的に行動する自律移動口 ボットシステム，特に美術館のような建物内に桧などのパ
ネルが複数かかっている璒境において，人間とともに歩き 回り説明をする案内ロボットシステムを実現した。人のロ ボット間の関係表現では，全方位視覚センサ HyperOmini Visionと全方位超音波距離センサ及び全方位赤外線近接セ

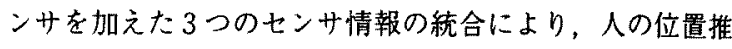
定を行った。そして，ロボットとユーザ間の距離を一定に 保つ定間隔行動を行うことで, ユーザの行動をロボットの 動作結果により表現した。

今後はより安定した人物の追跡のための改良を行い，人 物のジェスチヤの認識などより密なコミュニケーションを 通したシステムを実現したいと考える。

また，実際に案内ロボットを構築しようとした場合，口 ボットの周囲には，多くの人が存在し，それらの人を同時 に観測する必要が生まれる．特に，このような状況では， 今回の $3 つ の$ 全方位センサをシステムの利用価値が高いも のと考えられる，今回は，環境一人ーロボット三者の関保 に重きを扔いていたが，今後は，複数の人が混在する場合 へ発展させ，全方位センサ情報統合の方法について樑く検 討したいと考える。

なお, 本研究の一部は, 文部省科学研究費重点領域研究 (代表 谷内田)，基盤研究A（代表 谷内田）並びに奨 励研究A（代表 八木）の補助を受けた。

(平成 9 年 2 月 27 日受付, 平成 9 年 6 月 2 日再受付)

\section{文 献}

[1] 特集”人間と共存するロボットの新技術，人にサー ビスする新機械ーマシナサビエンスーをめざして”計 測と制御,34,4 (1995)

[2] 特集”医療福祉とロボティクス”,日本ロボット学会 誌, vol.14, no.5 (1996)

[3] 安西祐一郎: "多重知覚情報の相互関連モデルの研究", 科研重点領域報告書「感性情報処理の情報学・心理学 的研究」,pp.9-12, 平成 7年1月

[4] M. Yachida, Ichinose and S. Tsuji, Model-Guided Monitoring of a Building Environment by a Mobile Robot, IJCAI, vol.2 1125-1127 (1983)

[5] 石黒, 前田, 辻, 全方位画像記憶に基づくロボット の誘導、ロボットシンポジゥム,139-144 (1995)

[6] 柴田, 坂井, 松本, 稲邑, 稲葉, 井上:Hyper Scooter の研究ー梘覚情報に基づいた前方を走行するユーザの 追跡走行一，ロボテイクスシンポジア, 23-28 (1996)

[7]石川繁樹，浅香俊一：移動障害物を含むような動的変 化を伴う走行環境における自律移動ロボットの走行誘 導方式, 日本ロボット学会誌, 11,6,856-867 (1993)

[8] 佐藤, 西田, 市川, 畑村, 溝口:ロボットによる人間の 意図の能動的理解機能, 日本ロボット学会誌, vol.13, no.4, 545-552 (1995)

[9] Y. Cui, D. L. Swets and J. J. Weng, Learning-Based Hand Sign Recognition Using SHOSLIF-M, Int Conf. 
Computer Vision (1995)

[10] R. Chellappa, C. L. Wilson ans Saad Sirohey, Human and Machine Recognition of Faces : A Survey, Proc. The IEEE, 83, 5, 705-740 (1995)

[11] 中村裕一, 太田友一:話者行動理解のための動作解析 システム, 第 2 回重点領域研究「知能ロボット」シン ポジウム, 123-126 (1996)

[12] 佐藤和也, 八木康史, 谷内田正彦: 全方位視覚を用い た案内ロボットシステム, ロボティクスシンポジア, 35-40 (1996)

[13] K. Yamazawa, Y. Yagi and M. Yachida ," Omnidirectional Imaging with Hyperboloidal Projection ", Proceedings IEEE/RSJ Int. Conf. Intelligent Robots and Systems,vol.2,pp.1029-1034 (1993)

[14] Yasushi Yagi, Yoshimitsu Nishizawa, Masahiko Yachida,"Map-Based Navigation for a Mobile Robot with Omnidirectional Image Sensor COPIS, IEEE Transactions on Robotics and Automation, vol11, no.5, pp.634-648(Oct.1995)

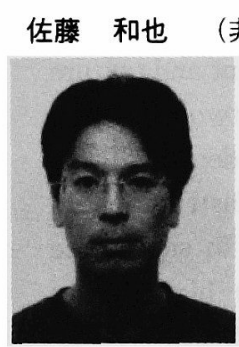

（非会員）1971年4月21日生. 1994年大阪 大学基䃈工学部制御工学科卒業. 1996 年同大大学院博士前期課程修了. 同年キャ ノン入社. 工学修士. 日本ロボット学会 会員.

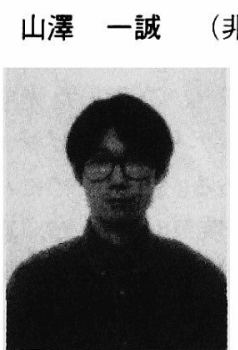

(非会員) 1970年3月12日生. 1992年大阪 大学基礎工学部情報工学科卒業。1 1994 年同大大学院博士前期課程修了. 1996 年同大大学院博士後期課程中退. 同年奈 良先端科学技術大学院大学情報科学研究 科助手. 現在に至る. 平成 8 年度電子情 報通信学会論文賞, ロボットビジョン, バーチャルリアリティの研究に従事. 工 学修士. 電子情報通信学会会員.

八木 康史 (非会員) 1959年9月27日生. 1983年大阪

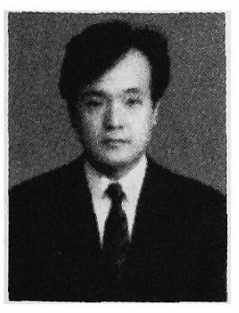
大学基礎工学部制御工学科卒業. 1985 年同大大学院修士課程修了. 同年三菱電 機 (株) 入社. 同社産業システム研究所 にてロボットビジョンの研究に従事. 1990年大阪大学基礎工学部情報工学科 助手. 1993年同学部システム工学科講 師. 現在同学科助教授. 1995年 1996 年英国オックスフォード大学客員研究員, 平成 8 年度電子 情報通信学会論文賞, IEEE, 電子情報通信学会, 情報処理 学会, 日本ロボット学会, システム制御情報学会等各会員.
主として全方位視覚に関する研究を行っている. 工学博士.

谷内田 正彦 (非会員) 1945年9月4日生. 1971年大阪

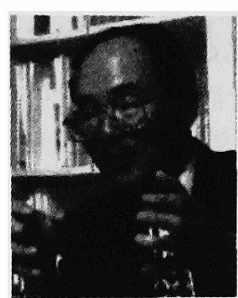
大学大学院工学研究科修士課程修了. 同 年同大基礎工学部制御工学科助手. 同助 教授を経て同学部情報工学科教授. 1993年同学部システム工学科教授、現 在に至る.1967～1968年デンマーク原 子力研究所留学. 1972－1973年米イリ ノイ大学にてResearch Associate. 1980 〜1981年西独ハンブルグ大学Research Fellow. 1982年米 ミネソタ大学 CDC Professor. 平成 8 年度電子情報通信学 会論文賞, 情報処理学会、ロボット学会、人工知能学会等 会員. 著書ロボットビジョン (昭晃堂)、コンピュータビ ジョン (丸善、編著) 等. コンピュータ・ビジョン、人工 知能, 移動ロボットなどの研究を行なっている. 工学博士. 